\title{
Habonaron Do Bona and Sapangambei Manoktok Hitei Symbols Interpreted as Simalungun Ethnic Identity in Regional Autonomy
}

\author{
Hadiani Fitri \\ Faculty of Teacher Training and \\ Education \\ Islamic University of North Sumatera \\ Medan, Indonesia \\ hadianifitri@gmail.com
}

\begin{abstract}
Interpretation of symbols in Simalungun pictures the benchmark the ethnic's identity and activity, including their governing system. Symbols which underlie the life of Simalungun ethnic are called Habonaron Do Bona and Sapangambei Manoktok Hitei. Habonaron Do Bona, which means of the truth, is the most basic and important thing that covers the whole aspects of life. It becomes a symbol of Simalungun Government recognized as a symbol that means of upholding the truth. This term can be accumulated in the daily activities of Simalungun ethnic who has ahap Simalungun. This research finds posiive influence of Habonaron Do Bona and Sapangambei Manoktok Hitei, meaning something is done together, then the purpose or what aspire will be quickly achieved and implemented. Like building a bridge, it cannot be finished alone, but with a lot of people, it means that when they do mutual cooperation, it will be quickly finished to make the great bridge that eventually develop the acceleration of progress and prosperity with the truth.
\end{abstract}

Keywords-ethnic identity, Simalungun ethnic, Habonaron Do Bona, Sapangambei Manoktok Hitei, regional autonomy (keywords)

\section{INTRODUCTION}

Every significative theme which links the real regions could be defined as a symbolic and linguistic modus with achieved transcendence could be called symbolic language. Then, in symbolism level, a linguistic significance which totally apart from "here and now" in daily life and language spreads widely entering regions that not only de facto but a priori cannot enter in daily experience. Language is not only for building abstracted symbols from daily experience but also for returning and bringing it back as a real element in daily life. Through this way, symbolism and symbolic language can be essential elements and common sense understanding about the fact in daily life, life instruction and a symbol of the world (individual) [1].

Ferdinand de Saussure in Berger dan Luckmann [1] researched how culture system can unite many people being a relatively cohesive community, and also establish customs and traditions by having last long life with language. As well as the community establish communication by involving some inseparable aspects such as language system. Language system (langue) or linguistic system from sign or rule that interpret a certain language and 'speech' or 'phrase suite (words)' (parole) use these signs to bring the message in the communication process. Individual linguistic signs (the words spoken or written) obtain meaning from its relation to the other signs in the certain language system. This 'code' includes vocabulary, grammar and voice patterns which interpret a certain language needed by every individual for speaking or writing and understanding. Those are the collective character of the population, experienced and learned through socialization from their members. The other culture signs (such as pictures, art sculpture, and shape of clothes) are also organized in codes interpreting how they can be combined to bring the message. Meanwhile, some of these signs are carried or delivered linguistically, but they might be analyzed in the same way as language.

Realized that the member of the population is formed by being a specific group through their own ideas and cultural values. By this means, they are able to establish a systematic relation that arranges them as 'society.' Members of the society will be social and proper 'human' if only their activities are organized from their own shared ideas. Those ideas and social relationships are specifically seen as social 'system' composer with unique character and autonomy which can be sociological research objects. People who point out the culture formation problem tend to adopt interpretative reference framework of cultural unity which should be 'understood' by learning the meaning of individual characters and culture items. On the other hand, people who point to analyze about system characters tend to adopt casual reference framework according to the focus of attention which should be directed to the relation among 'organ' or subsystem and produced processes tenable its 'equilibrium' [2].

Revealing the 'truth' is something that quite difficult and complicated for Simalungun ethnic in an effort to know the meaning and understanding of that word. Not everyone can understand the meaning what contained in that 'truth' word even though there are some parties who know why that word needs to be the symbol or philosophy because that thing is related with an attitude which should be maintained and exist in every human self. Because that thing is closely related to behavior, action, ethics and moral. The truth sometimes subjective or objective depends on someone who has the ability or desire to understand the purpose contained in that "truth" word which expected be able to manifest Simalungun people as 
ahap so it is also able to be perceived and reduced by the other people, so it really can be useful.

The meaning of those symbols in Simalungun about truth addressed to some parties which contained expectation given to group party considered a leader in custom, social organization, and government. They should implement the truth words appropriate to their behavior and action which related to those symbols. So, it can be benchmark view which can be reduced with behavior or action in their daily life for actualizing harmonic interaction, including mutual cooperation, which means that together with the truth to build acceleration progress and prosperity. The symbols are interpreted in regional autonomy by Simalungun ethnic, i.e. Habonaron Do Bona and Sapangambei Manoktok Hitei. Regional autonomy is a chance to Simalungun ethnic existence for being recognized and evolved to be something which can change Simalungun ethnic perspective of their world (Habonaron Do Bona land).

\section{MATERIAL AND METHODS}

The study in this research intended to understand and compose concepts of Habonaron Do Bona and Sapangambei Manoktok Hitei symbols that interpreted as Simalungun ethnic identity in regional autonomy. This research is qualitative using phenomenology approach. The study of phenomenology is an attempt to understand consciousness as experienced from the point of view of the first person [3]. Literally, phenomenology is the study of phenomena, or about everything that appears to a person in subjective experience, or about how a person experiences everything around him/her. Phenomenology can learn forms of experience from the point of view of people who experience it directly as if experiencing it personally.

Phenomenology not only classifies any basic action taken but also includes predictions of future action, in view of the aspects associated with it. All of that comes from how someone interpreted the object in his/her experience [4]. The phenomenological approach adopted in this study is an attempt to conduct qualitative exploration in relation to the study of the Habonaron Do Bona and Sapangambei Manoktok Hitei symbols that interpreted as Simalungun ethnic identity in regional autonomy [5].

Determination of research subjects conducted by representative or perceived capable and able to answer research questions in accordance with Spradley's [6] statement that there are five minimum requirements to select a good informant, i.e., full enculturation, direct involvement, cultural atmosphere that is not known to researchers, enough time, and non -analytic. The research was conducted in Simalungun Regency, especially in Pematang Raya which became the capital of Simalungun. The instrument in this study is the researcher herself and uses interview guidelines that contain questions. Conducted with in-depth interviews, observation and retrieving documents. The research was conducted in Simalungun Regency, especially in Pematang Raya which became the capital of Simalungun.

This study was conducted by stages including data collection conducted by the researcher, data analysis done by the researcher, and presentation of data analysis result done by the researcher, discussion result of data analysis and theoretical implication done by the researcher. Data analysis in this study was done textually. Textual analysis is aimed at texts which is a manifestation of discursive practices.

\section{RESULTS AND DISCUSSION}

\section{A. Habonaron Do Bona as A Meaning of The Truth}

Habonaron Do Bona, which has a meaning of upholding the truth is an emblem of Simalungun Regency is a bond and strong symbol of Simalungun ethnic identity. It means that in social life, the truth and honesty is the main base for making interaction with fellow Simalungun ethnic or immigrant ethnic. So that all ideas can be successful and useful for the prosperity and progress. Related to the construction of ethnic identity, it is needed honesty, the foundation of Simalungun ethnic culture. Habonaron Do Bona is recognized as a symbol of Simalungun Regency Government has a meaning that 'honesty above all' or upholding honesty which can be accumulated in life activity of Simalungun ethnic who has ahap Simalungun.

There is history explained about the formation of Habonaron Do Bona as something identical with 'truth.' Between Simagod and Sinumbah called on top of one another and unique namely Simagod Habonaran. The followers were brought to the right path, and they must get a reward. Simagod Habonaran conquered the other imaged in a number of followers. Simagod Habonaran worship would be called Parhabonaran continue applying heredity. More Habonaran followers who violate Habonaran in Simalungun which is in all tradition types of Habonaran value as its 'venter.' Simalungun parable is inseparable from Habonaron Do Bona [7]. The meaning of Habonaron Do Bona is the truth as the most basic and important thing.

Habonaron Do Bona which covers whole life aspect does not mean only the beginning right but should be right in the middle and the end. Like a plant, inseparable from the root, stem, branch, twig, leaf, and fruit, it also happens in the whole life Simalungun ethnic which must be in Habonaron Do Bona. Habonaron Do Bona as a symbol interpreted by Simalungun ethnic has ethical interest to implement culture study since the beginning and becomes one of a successor who will generate value. In a study of culture, sensitive to basic nature and cultural function, it should be realized on the ethical dimension. So, the concern for ethics and morality aspects should be the main and initial consideration in culture study.

Habonaron Do Bona is a vision and mission of Simalungun that must be socialized and cultivated, so it should be attached to Simalungun ethic, such as through wearing Simalungun batik dress. Concisely, the meaning of Habonaron Do Bona is the true principle, absolute, compulsion, and foundation to build a Simalungun identity. Habonaron Do Bona should consistently implement by Simalungun ethnic in their life. Preservation and cultivation of "truth" in themselves are absolute and have no relative meaning. It should be the identity of Simalungun ethnic for showing and strengthening their existence. 
In culture study [8], recognizing the power of mastery and resistance can help political struggle process and release from operation and authorization. In this side, ethics tends to be defeated toward politics and culture moral dimension tends to be underestimated and degraded. Then people can support culture study which explicitly emphasizes the importance of ethics analyze, textual research culture for getting ethical norms, ideal and specifically depicted value and evaluate the work based on the things which usually do in culture study. That is how they made moral criticism to society and culture or actualized ethical interest which includes goodness and wickedness, conceptualized behavior or phenomenon of moral and immoral.

\section{B. Sapangambei Manoktok Hitei as A Meaning of The Mutual Cooperation}

Sapangambei Manoktok Hitei means the priority of togetherness to do work, especially a mutual cooperation. If something is done together, then the purpose or what aspire will be quickly achieved and implemented. The meaning of togetherness is doing something related to custom or tradition of Simalungun ethnic which should be as a pride together. It is associated with the self-identity of Simalungun ethnic, even though there are so many another thing that should be done related to identity movement as Simalungun ethnic. Sapangambei Manoktok Hitei means do something together, like building a bridge, it cannot be finished alone, but with a lot of people, it means that when they do mutual cooperation, it will be quickly finished to make the great bridge. Sapangambei Manoktok Hitei means building the bridge done together for finishing it quickly. However, Simalungun society not only builds the bridge but also recognize it as a change. Sapangambei Manoktok Hitei is mutual cooperation which philosophically prioritizes togetherness to do all the things. Sapangambei Manoktok Hitei is building together for the advancement of Simalungun Regency.

Sapangambei Manoktok Hitei is something identified with togetherness. Employment and development for progress and prosperity of Simalungun ethnic must be done together which means not only think about selfishness from any parties. In addition to doing change for better progress and prosperity together, Simalungun ethnic should also participate to face that change.

In real daily life, we live together with others in this intersubjective world which distinguish the reality in daily life with other realized reality [1]. Being alone in the dream world, but knowing that daily life world as real for the others. We can't exist in daily life without continuously have interaction and communication with the others. Natural attitude to this world should be suitable with natural attitude to the others who also comprehend various objectivation organized this world, organize "here and now" from their existence in the world and have a mutual activity to be done. Every person in the world must have their own perspective, and there must be a different perspective from the others although they live in the same world. Conformity must continuously occur so that people can realize a fact in real life. Actions that become habits still preserve the individual character, although its involved meanings have embedded as routine in provision common knowledge, which is received and provided for projects in the future. Habituation can give the psychological advantage that choices become narrowed. It liberates the individual from burden all decisions and gives psychological relief basically found in the structure of undirected human instinct. By giving a stabilized background which human activity can be held almost all the time with the requirement of taking only the minimal decision, it can save the energy for making decisions that are necessary for certain chances. In the other word, accustomed activity background opens the plan and innovation for the future [1].

\section{CONCLUSION}

This research has indicated that Simalungun Regency has influenced positive impacts in strengthening the values of their ethnic identity The interpreted symbols like Habonaron Do Bona and Sapangambei Manoktok Hitei are still firm understood, comprehended and implemented by Simalungun ethnic.

Habonaron Do Bona as the true symbol makes Simalungun ethnic still uphold the truth as the main thing in their life in culture, politic, and communication with Simalungun citizens expected to be able to give a blessing in their lives. Sapangambei Manoktok Hitei as mutual cooperation symbol that increases the sense of togetherness as Simalungun ethnic who should help each other in every life aspect, participate in building the change and taking the chance in the change for prosperity life.

\section{REFERENCES}

[1] Peter L. Berger and Thomas Luckmann, "Social Construction of Reality: A Treatise in the Sociology of Knowledge," New York: Anchor Book, 1967.

[2] Scott, J., (Social Theory: The Central Issues in Sociology) "Teori Sosial: Masalah-Masalah Pokok Dalam Sosiologi," (translated), Yogyakarta: Pustaka Pelajar, 2012, p. 52.

[3] Muslih, M, (Religious Plus Intuitive Consciousness: Husrel infront of Sahrawardi Mirror) "Kesadaran Intuitif Plus Cahaya Ilahiyah: Husserl di Muka Cermin Sahrawardi," Jurnal Tsaqofah,_2006, Vol. 4, No. 2, p. 260.

[4] Kuswarno, E., (Phenomenology) "Fenomenologi," Bandung: Widya Padjajaran, 2009, pp. 10-12.

[5] Hadeli, (Research Method in Education) "Metode Penelitian Kependidikan," (translated) Padang: Quantum Teaching, 2006, p. 73.

[6] Spradley, J. P., (Ethnography Method) "Metode Etnografi," (translated) Yogyakarta: Tiara Wacana, 2007, p. 68.

[7] Sumbayak, St. J., Fleksi Habonaron Do Bona dalam Adat Budaya, 2001, no publisher, pp. 76-77.

[8] Ritzer, G. and Barry S, Handbook Teori Sosial (translated), Bandung: Nusa Media, 2011, p. 807. 